\title{
Diffuse idiopathic skeletal hyperostosis (DISH): a clinical study
}

\section{Difüz idiyopatik iskelet hiperostozu (DISH): klinik çalışma}

\author{
Mustafa Öğden ${ }^{1}$ (D), Ulas Yüksel ${ }^{2}$ (D), Suleyman Akkaya ${ }^{1}$ (D), Jonathan Oppong ${ }^{3}$ (D), Üçler Kısa ${ }^{4}$ (D), \\ Bulent Bakar ${ }^{1}$ (D), Mehmet Faik Ozveren ${ }^{1}$ (i) \\ ${ }^{1}$ Kırıkkale University, Faculty of Medicine, Department of Neurosurgery, Kırıkkale, Turkey \\ ${ }^{2}$ Yıldırım Beyazıt University, Yenimahalle Training and Research Hospital, Neurosurgery Clinic, Ankara, Turkey \\ ${ }^{3}$ Kırıkkale University, Faculty of Medicine, Kırıkkale, Turkey \\ ${ }^{4}$ Kırıkkale University Medical Faculty, Department of Biochemistry, Kırıkkale, Turkey \\ * Corresponding Author: Mustafa Öğden E-mail: mustafaogden38@gmail.com ORCID: 0000-0002-7129-0936 \\ Received: 6 June 2018 Accepted: 14 August 2018
}

\begin{abstract}
Aim: Diffuse idiopathic skeletal hyperosteosis (DISH) characterized by formation of disseminated osteofites on vertebra in the absence of traumatic or post infectious changes is a chronic disease of unknown etiology. This study was aimed to investigate the biochemical relationship of DISH in patients with DISH.

Material and Method: Eleven patients diagnosed with DISH (DIH group) and eleven patients with axial pain but without any vertebral disease (Control group) who applied to the neurosurgery clinic between the years 2016-2017 were enrolled in this retrospective study. HLA-B27 antigen positivity, erythrocyte sedimentation rate, leukocyte, basofil and eosinophil counts, C-reactive protein, phosphorus and calcium levels, and their results in individuals were investigated. Anteroposterior and lateral pelvis, knee, lateral foot radiograms showing extra-axial involvement were viewed.
\end{abstract}

Results: Of the patients with DISH, one owing to difficulty in swallowing and another owing to quadriplegia as a result of cervical trauma underwent surgical therapy. Radiological investigations of this group revealed iliac involvement in four patients and patellar joint involvement in one patient. There was no difference between groups with respect to age, sex, leucocyte, basophil and eosinophil count, C-reactive protein, phosphorus and calcium levels. However there was a significant difference with respect to dysphagia and extra-axial involvement. No individual was positive for HLA-B27 antigen.

Conclusion: Present study findings suggested that both acute and/ or chronic inflammatory processes have no place in the etiology of this disease.

Keywords: DISH, diffuse idiopathic skeletal hyperostosis, comorbidity

() 2019 by the authors; licensee MEDITAGEM Ltd., Turkey. This article is an open access article distributed under the terms and conditions of the Creative Commons Attribution License (http://creativecommons.org/licenses/by/4.0/). 


\section{öz}

Amaç: Yaygın idiopatik iskelet hiperosteozu (DISH) henüz sebebi bilinmeyen, travmatik veya inflamatuvar değişiklik olmaksızın omurgada, diğer eklemlerde ve ligamentlerde yaygın kalsifikasyonla karakterize kronik bir hastalıktır. Bu çalışmada DISH sendromuyla eşlik eden hastalıklar ve rutin biyokimya laboratuar bulguları arasındaki ilişki araştııılı.

Gereç ve Yöntem: Çalışmaya 22 kişi (DISH grubu: 11; Kontrol grubu: 11) alındı. Bireylerde disfaji, komorbidite (diyabetes mellitus, esansiyel hipertansiyon, romatolojik hastalık) sorgulandı. HLAB-27, eritrosit sedimantasyon hızı(ESR), beyaz küre sayımı, C-reaktif protein, fosfor, kalsiyum düzeyleri incelendi. Ekstraaksiyel (omurga dışı) tutulumları göstermeye yönelik anteroposterior-lateral pelvis, diz ve lateral ayak röntgenleri görüldü.

Bulgular: DISH sendromu olan tüm bireylerde HLAB-27 negatif bulundu ve 1 hasta yutma güçlüğü ve 1 hasta düşme sonrası gelişen parapleji nedeniyle opere edildi ve 3 hastada omurga dışı tutulum (sakroiliak eklemlerde, patella ve aşil tendonda) saptandı. íki grup arasında laboratuvar değerleri bakımından istatistiksel farklılık saptanmadı. Diğer yandan DISH grubunda ekstraaksiyel tutulum ile beyaz küre $(r=-0.748, p=0.013)$, C-reaktif protein $(r=-0.635, p=0.036)$ düzeyleri arasında ve disfaji ile eozinofil düzeyi ( $r=-0.719, p=0.013)$ arasında negatif korelasyon saptandı. DISH sendromu ile yaş, cinsiyet, komorbidite ve diğer laboratuvar değerleri arasında korelasyon bulunmadı.

Sonuç: Bu çalışmada her ne kadar çalışma grubu küçük olsa da DISH sendromunun ekstraaksiyel tutulum da yapabildiği, seronegatif bir hastalık olduğu, romatizmal hastalıklardan farklı olarak kan biyokimya değerlerinde bir anormalliğe neden olmadığı teyit edildi. Diğer yandan özellikle servikal ve torakal tutulumu olan hastaların klinik takibinde travmaya ikincil gelişebilecek kuadripleji/parapleji yönünden dikkatli olunması gerektiği düşünüldü.

Anahtar kelimeler: yaygın idiopatik iskelet hiperosteozu, ekstraaksiyel tutulum, komorbidite, lökosit, C-reaktif protein, kalsiyum

\section{INTRODUCTION}

First defined by Forester in 1950, "diffuse idiopathic skeletal hyperostosis" (DISH) (Ankylosing hyperostosis, Forestier's Disease, Spondilitis Ossificans ligamentosa) is a chronic disease with increased incidence with age and three times more frequently seen in males. It is characterized by the formation of diffuse osteofitic and ligamentous calcifications on the vertebrae in the absence of trauma or post infectious changes [1,2]. Although the etiopathogenesis of this disease is not well known, it has been proposed that it is triggered by situations such as diabetes mellitus, hyperuricemia, hypertension, obesity, old age, and hyperinsulinemia [1,3]. These calcifications were characterized by candle-wax like ossifications on especially the anterior longitudinal ligament and was named in literature as "candle-wax" [4]. These osteophytes as could only be on the vertebra could also be on tendons, ligaments and joint capsules in extra-axial regions. The calcaneus, patella, ulna, "os-coxa", wrist, hip, shoulder, knee, sacroiliac, iliolumbar and other joints have been reported to be the most frequently involved extra-axial regions. Furthermore, cases of chondrocalcinosis, ectopic enthesal calcifications, vessel calcifications and nephrolithiasis have been reported in literature as co-diseases $[5,6]$.
In this study, patients with DISH were discussed and the relationship of the disease with biochemical parameters was investigated.

\section{MATERIAL AND METHOD}

Material: The protocol and design of this study was approved by the local ethical and scientific committee (Ethics Committee of Kirikkale University; Date: 12.12.2017 and approval number: 24/04).

Eleven patients diagnosed with DISH (DISH group) and eleven patients with axial pain but without any vertebral disease (Control group) who applied to the neurosurgery clinic between the years 2016 - 2017 were enrolled in this retrospective study. Patients were included in the study by using three different diagnostic criteria described in literature for the diagnosis of DISH (Table 1). Patients were questioned on difficulty in swallowing and co-morbidity (such as diabetes mellitus type I or type II, hypertension). The results of laboratory examinations of HLA B27 (Human Leucocyte Antigen B27) antigen positivity, erythrocyte sedimentation rate, leucocyte, basophil and eosinophil count, C-reactive protein, phosphorus and calcium levels were investigated in individuals of this study. To show extra- 
Table 1. Descriptive table of "DISH diagnostic criteria" described by Forestier, Resnick and Utsinger

\begin{tabular}{|l|l|}
\hline Forestier' criterias \\
\hline Stage I & Ligament calcification and ossification without ankylosis \\
\hline Stage II & Flame like ossification \\
\hline Stage III & $\begin{array}{l}\text { Formation of thick new bone formation anterior to } \\
\text { vertebra body. }\end{array}$ \\
\hline Resnick's criterias \\
\hline 1 & $\begin{array}{l}\text { Paraspinal longitudinal ligament calcification and } \\
\text { ossification continuing along at least four vertebrae levels }\end{array}$ \\
\hline 2 & $\begin{array}{l}\text { No disk degeneration, protected or slight reducted disk } \\
\text { space }\end{array}$ \\
\hline 3 & No other finding of degenerative spinal joint diseases. \\
\hline Utsinger's criterias \\
\hline Definite DISH & $\begin{array}{l}\text { First of all, there are continuity of the four thoracolumbar } \\
\text { vertebral arches, minimal intervertebral disc disease and } \\
\text { facet joint ankylosis. }\end{array}$ \\
\hline Possible DISH & $\begin{array}{l}\text { Anterolateral ossification along at least two vertebra } \\
\text { corpus }\end{array}$ \\
\hline Likely DISH & $\begin{array}{l}\text { In bone and ligament junctions, symmetric and } \\
\text { peripheral enthesopathy in the posterior calcaneus, } \\
\text { superior patella, or olecranon, together with well-defined } \\
\text { new bone formation in the cortical margin }\end{array}$ \\
\hline
\end{tabular}

axial (non-vertebral) involvement, anteroposterior and lateral pelvis, knee and lateral foot x-ray films were viewed.

Biochemical Analysis: The venous blood of patients enrolled in the study were placed into biochemistry, hemogram and sedimentation tubes and sent to the biochemistry laboratory. Serum C-reactive protein, calcium and phosphorus levels were studied in the biochemistry laboratory by using original commercial kits (Roche) from a fully automated analyzer (Roche-Hitachi, Cobas C501, Roche Diagnostics, USA). CRP level (reference range 0.15-5 mg/L) was determined by the immunoturbidimetric method while the serum calcium level (reference range 8.6-10.0 mg/dL) and phosphorus level (reference range $2.5-4.5 \mathrm{mg} / \mathrm{dL}$ ) was determined by the ISE (ion selective electrode) method.

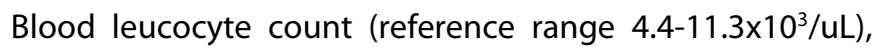
neutrophil level (reference range \%35-80) and eosinophil level (reference range \%0.0-33.0) was determined, again using a fully automated analyzing device (Mindray BC-6800, Shenzen, China). Erythrocyte sedimentation rate (reference range 0-20/hour) was evaluated by the erythrocyte sedimentation rate analyzer with "westergren method". Serum HLA B27 was observed by flow cytometry (BD Bioscience, USA).

Statistical Analysis: The age, leukocyte count, eosinophil and basophil count, erythrocyte sedimentation rate, Creactive protein, calcium and phosphorus levels of the patients were found to be homogeneous and normally distributed in the groups. For this reason, the Independent Samples $t$ test was applied to evaluate the difference
Table 2. Descriptive table of variables belonging to groups (min: min; max: max, SD, standard deviation)

\begin{tabular}{|c|c|c|c|c|c|}
\hline Group & Variable & Min & Max & Mean & SD \\
\hline \multirow{8}{*}{ CONTROL } & Age & 50 & 65 & 56.27 & 5.39 \\
\hline & Leukocyte & 5.32 & 12.00 & 8.46 & 2.26 \\
\hline & Eosinophil & 0.03 & 0.61 & 0.20 & 0.20 \\
\hline & Basophil & 0.01 & 0.07 & 0.04 & 0.02 \\
\hline & $\begin{array}{l}\text { Erythrocyte } \\
\text { sedimentation rate }\end{array}$ & 5.00 & 49.00 & 22.64 & 16.31 \\
\hline & C-reactive protein & 0.62 & 16.00 & 4.96 & 4.98 \\
\hline & Calcium & 8.98 & 10.00 & 9.45 & 0.33 \\
\hline & Phosphorus & 2.10 & 4.72 & 3.44 & 0.67 \\
\hline \multirow{8}{*}{ DISH } & Age & 51 & 73 & 62.00 & 8.45 \\
\hline & Leukocyte & 6.41 & 12.27 & 8.65 & 1.72 \\
\hline & Eosinophil & 0.06 & 1.24 & 0.28 & 0.33 \\
\hline & Basophil & 0.02 & 4.00 & 0.40 & 1.20 \\
\hline & $\begin{array}{l}\text { Erythrocyte } \\
\text { sedimentation rate }\end{array}$ & 5.00 & 59.00 & 21.09 & 15.89 \\
\hline & C-reactive protein & 0.79 & 14.00 & 4.23 & 4.32 \\
\hline & Calcium & 8.43 & 10.00 & 9.51 & 0.42 \\
\hline & Phosphorus & 1.90 & 4.39 & 3.43 & 0.77 \\
\hline
\end{tabular}

between the groups. Patients' gender, dysphagia, comorbidity and extra-axial involvement scores were not homogeneous and not normally distributed in the groups. For this reason, the Mann Whitney $U$ test was used to evaluate the difference between the groups was applied.

For all statistical tests, $\mathrm{p}<0.05$ was considered statistically significant.

\section{RESULTS}

The mean age of the control group (male $=6$, female $=5$ ) was $56 \pm 5.39$ and there was no other disease except for type II DM in 3 patients and hypertension in 1 patient.

The mean age of DISH group (male: 6, female: 5) was $62 \pm 8.45$, and 2 patients had type II DM and 2 patients had hypertension. Seven of the patients had swallowing difficulty and one was advanced enough to require surgical treatment. Surgical treatment was performed in 2 patients (due to the difficulty of swallowing in 1 patient and quadriplegia after cervical trauma in 1 patient) as described below. On radiological examinations, it was also found that 5 of these patients had extra-axial involvement (4 iliac junctions, 1 patellar ligament).

No statistically significant differences were found between the study groups in terms of age, sex, co-morbidity, erythrocyte sedimentation rate, leukocyte, basophil and eosinophil count, C-reactive protein, phosphorus and calcium levels. However, there was a significant difference between groups in terms of swallowing difficulty $(Z=-3.130$, $p<0.002)$ and extra-axial involvement $(Z=-2.806, p<0.005)$

(Table 2, Table 3). 
Table 3. No statistical difference was found between the study groups in terms of age, gender, co-morbidity, erythrocyte sedimentation rate, leucocyte, basophil and eosinophil count, Creactive protein, phosphorus and calcium levels. However, there was a significant difference between groups in terms of swallowing difficulty and extra axial involvement scores (t: $t$ score, Z: Z score)

\begin{tabular}{|l|c|c|}
\hline Variable & $\mathbf{t / Z}\left(^{*}\right)$ & $\mathbf{P}$ \\
\hline Age & 1.896 & 0.073 \\
\hline Gender & $0.000^{*}$ & 1.000 \\
\hline Diabetes mellitus & $-0.497^{*}$ & 0.619 \\
\hline Hypertension & $0.000^{*}$ & 1.000 \\
\hline Dysphagy & $-3.130^{*}$ & $\mathbf{0 . 0 0 2}$ \\
\hline Extraaxial involvement & $-2.806^{*}$ & $\mathbf{0 . 0 0 5}$ \\
\hline Leukocyte & 0.216 & 0.075 \\
\hline Eosinophil & 0.670 & 0.511 \\
\hline Basophil & 0.996 & 0.331 \\
\hline Erythrocyte sedimentation rate & -0.225 & 0.824 \\
\hline C-reactive protein & -0.365 & 0.719 \\
\hline Calcium & 0.364 & 0.720 \\
\hline Phosphorus & -0.035 & 0.972 \\
\hline
\end{tabular}

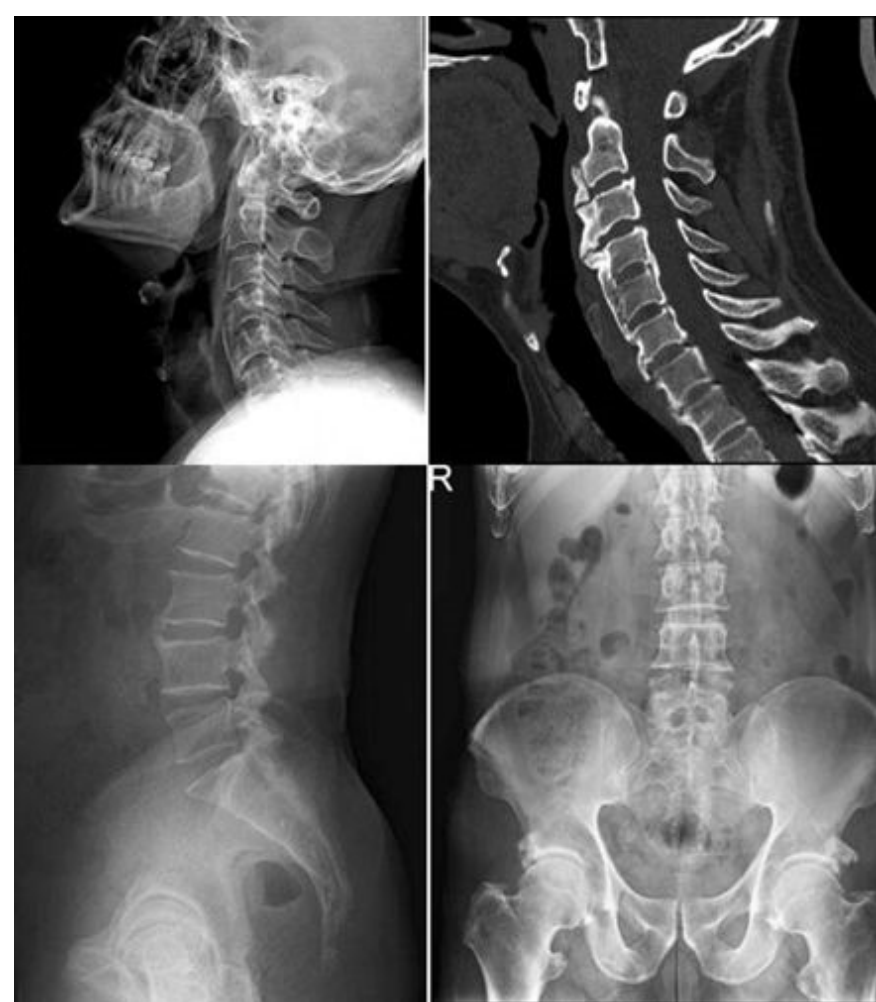

Figure 1. The radiological examination of the patient revealed extraaxial stiffness in the lumbar vertebrae and bilateral iliac wings as well as the cervical vertebrae

HLAB27 antigen positivity was not detected in any of the subjects studied.

Case 1: A 54-year-old male patient presented with a neck pain complaint of 4.5 years. His history included hypertension, smoking, 3 attacks of pancreatitis and nephrolithiasis. There was no feature in her family history. Muscle strength loss, pathologic reflex and spurling was not found on physical examination except for limitations in neck

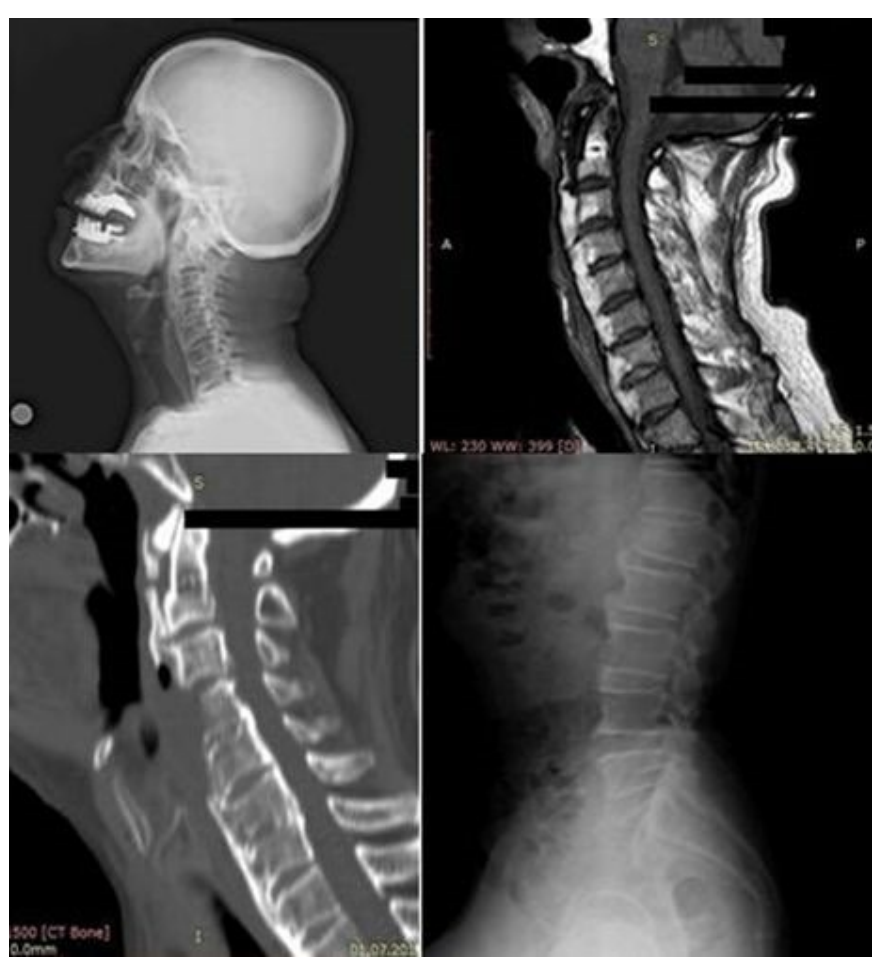

Figure 2. Cervical magnetic resonance imaging of the patient who was operated due to swallowing difficulty did not reveal myelopathy, but hyperostosis was observed on the frontal side of the lumbar vertebra

movement. Radiologic examination of the patient revealed extra-axial involvement in the lumbar vertebrae and bilateral iliac wings as well as the cervical vertebrae (Figure $1)$.

Case 2: A 70-year-old male patient was admitted with the complaint of increased swallowing difficulty for the last 1 month. The severity of the complaint with fluid or liquid food did not change. There was no feature in the personal history. Physical examination showed no pathological reflex and no loss of strength except for limitation of neck movements. On the cervical x-ray imaging of the patient, calcified formations revealing anterior bridging of all vertebra corpuses between the C2-C3-C4-C5-C6-C7 vertebrae, and simultaneously, similar images were seen on the anterior surfaces of the lumbar vertebrae. An appearance of myelopathy on cervical MR images was not detected. The patient was operated on because of the complaints of difficulty in swallowing. There was no problem in the long-term follow-up of the patient after surgery as his complaints of difficulty decreased (Figure 2).

Case 3: A 54-year-old woman presented with progressive neck pain, limitation of neck movements, and difficulty in swallowing for one year. The difficulty in swallowing did not change with the food being either solid or liquid. Her history included diabetes mellitus, essential hypertension, and 


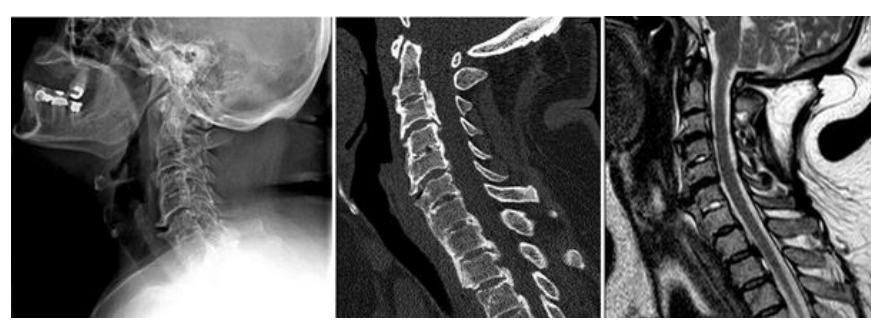

Figure 3. Common hyperostosis was detected in the anterior surface of the cervical vertebrae in radiological images of the patient, who were examined because of difficulty in swallowing

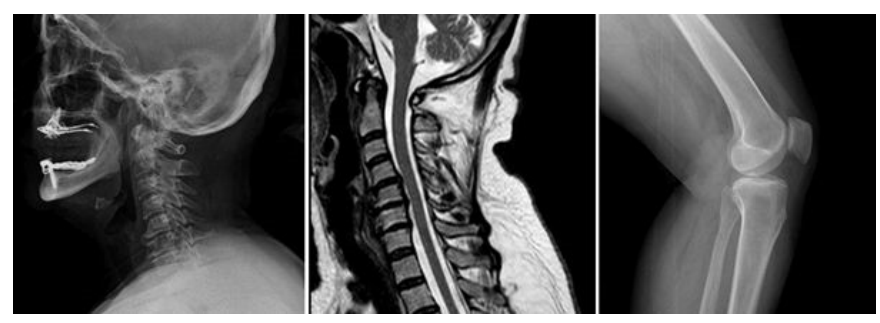

Figure 4. Patellar ligament calcification was detected on the bilateral knee direct radiograph of the patient who was admitted with a moderate level of swallowing difficulty

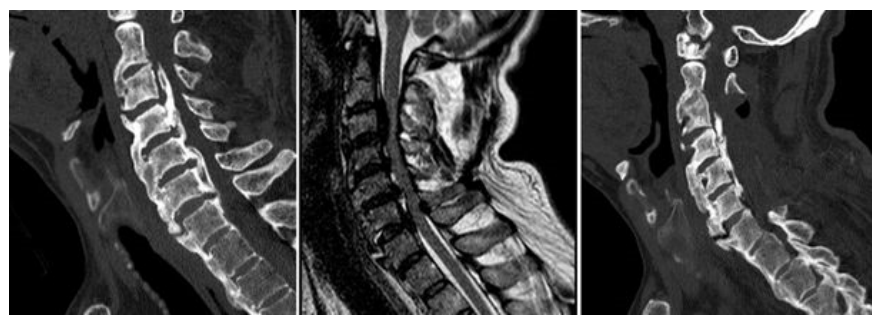

Figure 5. Preoperative and postoperative radiological findings of the patient with sudden weakness in his arms and legs after falling from the back of the chair showed extensive hyperostosis in both the anterior and posterior sides of the cervical vertebrae

coronary by-pass surgery. On physical examination, muscular strength loss, pathologic reflex and spurling findings were not detected except for limitation of neck movements (Figure 3).

Case 4: A 51-year-old male patient presented with a complaint of right-sided $\mathrm{C} 5$ radiculopathy and moderate swallowing difficulty. There was no feature on her history. Physical examination showed no loss of strength and no pathological reflex except for limitation of neck movements. Calcification of the patellar ligament was detected on bilateral knee direct radiographs (Figure 4).

Case 5: A 65-year-old male patient who fell to the back of a chair was brought with a complaint of weakness in the upper limbs and legs. The patient's history revealed that he was diagnosed with DISH at a health center with a complaint of motion restriction about 5 years earlier, and surgical treatment was suggested in this center due to severe narrowing of the cervical spinal canal. However, it was learned that the patient did not accept this treatment. On physical examination, the muscle strength of the proximal parts of both upper extremities was $3 / 5$ and distal 1/5; the muscle strength of the proximal and distal parts of both lower extremities was determined to be $0 / 5$. The patient was urgently operated upon and left hemilaminectomy was performed on the C3-4-5-6 vertebrae and bilateral ligamentum flavum was taken to relieve the spinal cord. Long-term follow-up of the patient revealed no improvement in neurological findings (Figure 5).

\section{DISCUSSION}

DISH prevalence was reported to be $25 \%$ in males and $15 \%$ in females aged $50-70$ years in the Anglo-Saxon population, but prevalence over 70 years increases to $35 \%$ in males and $26 \%$ in females. Higher prevalence values have been reported in Korean, Caucasian, and in the black African populations $[4,7]$. In the sample of this study, the average age was found to be about 62 and there was no difference in distribution between male/ female gender.

Although it has not yet been shown which etiologic factors are implicated in the formation of DISH, some metabolic diseases (such as hyperinsulinemia, diabetes mellitus, hypertension, dyslipidemia, Gout disease), obesity, coronary artery disease, prolonged isotretinoin use, fluoride excess in drinking water, high somatomedin-C level, HLA-B27 gene positivity, rheumatoid factor positivity and excessive vitamin $A$ intake were reported to be the risk factors in literature $[4,8,9,10]$.

In studies suggesting that abnormal osteoblast cell growth/ activity in the bone-ligament junction is involved in the pathogenesis of DISH, osteoblast cells are affected by many growth factors. Particularly that insulin-like growth factor-I increases alkaline phosphatase and collagen type II activities in osteoblasts and also that growth hormone is thought to increase local insulin-like growth factor-I and insulin-like growth factor binding protein synthesis in chondrocyte and osteoblast cells. Furthermore, it has been also argued that growth hormone and insulin levels are high in patients with DISH [12]. When the results of this study were examined, it was determined that only 2 of the 11 patients had DM and 2 had hypertension. There was no significant difference between the DISH group and the control group in both comorbidity and biochemical parameters. Although the number of samples was low in study groups, the results of statistical analysis suggested that diseases such as DM and/ or hypertension may not be a risk factor for the development of DISH. On the other hand, in the history of the patients, none of them were found to have excessive 
vitamin A use. In addition, the lack of differences in biochemical parameters among the study groups suggested that serum calcium, phosphorus, C-reactive protein levels, HLA-B27 gene positivity. and blood erythrocyte sedimentation rate, leucocyte, neutrophil, eosinophil counts were not effective in the formation of this disease. Although the biochemical parameters included in this study did not include rheumatologic markers (such as rheumatoid factor) and/ or the results of vasculitis markers, the present findings suggested that acute and/ or chronic inflammatory processes are not involved in the mechanism of this disease. Therefore, to support this hypothesis and to investigate the etiopathogenesis of this disease, it was considered necessary to constitute more advanced and detailed studies which discussed the biochemical parameters of patients with DISH (such as serume rheumatoid factor, parathormone, somatomedin- $\mathrm{C}$, thyroid hormone, cortisol, lipid, cholesterol, uric acid, bone alkaline phosphatase, and vitamin D3 levels).

Forestier, Resnick, and Utsinger described three different diagnostic criteria in literature for the diagnosis of DISH (Table 1) [2]. It has been reported that DISH is most likely to develop in the cervical vertebrae (55\%), followed by the thoracic (21\%), thoracolumbar (16\%) and lumber vertebrae (8\%) [11]. The most frequent symptoms of DISH have been reported to include pain and stiffness in the vertebrae, limited movement and in cases of advance degree of anterior longitudinal ligament (ALL) calcification, difficulty in swallowing due to pressure on the esophagus. [12]. When the data of the DISH group of present study was examined, it was observed that no patient had ankylosis and all patients met Forestier's diagnostic criteria. Furthermore, it was observed that all patients met Utsinger's diagnostic criteria for "possible DISH". It was determined that there was radiological involvement of the cervical axis in all patients in DISH group and that this involvement caused a marked limitation in neck movements. Again, it was found that seven of these patients had difficulty in swallowing and one had severe neurologic loss (quadriparesis) following trauma.

Since the etiopathogenesis of this disease has not yet been fully explained, no definite information has been obtained about the treatment of this disease in literature. Most researchers suggested that the treatment of the disease is symptomatic (such as analgesic and anti-inflammatory drugs, physiotherapy) and supportive. Furthermore, it was argued that in the presence of comorbid metabolic diseases, the treatment and/or remission of such diseases could be beneficial and could decrease the possibility of future cardiovascular diseases and even reduce the ossification of soft tissues such as muscles. They also suggested that careful attention should be paid to possible complications (such as spinal fractures, soft tissue and especially spinal cord compression due to heterotopic ossification, joint limitation and additional complications of these) [13]. In literature, the duration of symptoms and severity are taken into consideration when deciding on surgical treatment for DISH patients. It has been reported that the esophagus is under pressure, the epiglottis is mechanically affected, that aspiration pneumonitis can occur in these patients, and that surgical treatment should be considered first in such patients, especially in cases of severe hyperostosis of C4-C5 vertebrae of the anterior longitudinal ligament. It has also been reported that, if anterior longitudinal ligament calcification and posterior longitudinal ligament calcification are also present, patients with cervical involvement may develop neurological loss, even in patients with myelomalacia and a possible trauma, and even mortality in some patients. Calcifications causing cervical spinal narrowing have also been reported to cause serious neurological loss even after flexion and/or extension type minor trauma and it is suggested that surgical treatment should be considered first in such patients. It is argued that to be able to perform surgery in the early stage, it is necessary to provide detailed information about the risks mentioned above and the possible legal problems $[12,14,15]$. As a matter of fact, this study showed that cervical involvement was present in all patients of DISH group, that this cervical involvement caused to develop complications which required surgical treatment in two patients (difficulty in swallowing in one patient and quadriplegia after trauma in the other patient). When we look at the sample of this study, it was determined that a serious degree of difficulty in swallowing occured in a patient with DISH disease and it was seen that surgical treatment was applied to the patient before the above mentioned complications appeared. On the other hand, it is thought that as was seen in the fifth sample case of the DIH group, patients with cervical and/or thoracal DISH could experience severe post traumatic neurological loss. When the patient's personal history was questioned, it was learned that the patient had a very longstanding DISH, that the patient was offered surgical treatment but that the patient refused this treatment. Especially in patients with cervical and / or thoracic DISH, the possibility of spinal cord injury is very high. Therefore, it is thought that preventive surgical treatments may be necessary to remove the effects of these ossifications before these complications occur and these patients should be urgently directed towards surgical treatment. 


\section{Limitations}

Certain limitations were observed in this retrospective study. First, the number of samples enrolled in the study was very little. However although it is thought that this is a rarely seen disease, it is thought that new information could be added to the body of literature relating to the clinical description of this disease. Second, because this was a retrospective clinical study, not every patient's laboratory blood values were studied into details and because of that biochemical parameters such as rheumatoid facor, parathormone, somatomedin-C, thyroid hormone, cortizol, lipid, cholesterol, uric acid, bone alkalene phosphatase and vitamin D3 were not obtained. Owing to this, more advanced and detailed studies featuring these biochemical parameters need to be conducted to investigate the etiopathogenesis of this disease in DISH diagnosed patients.

\section{CONCLUSION}

The results of this study suggested that both acute and/ or chronic inflammatory processes could not be involved in the mechanism of formation of this disease, and before complications of this disease set in, it may be necessary to perform prophylactic surgical treatments to remove the effects of hyperostosis, especially in cervical and/ or thoracic DISH patients.

\section{DECLARATION OF CONFLICTING INTERESTS}

The author declared no conflicts of interest with respect to the authorship and/or publication of this article.

\section{REFERENCES}

1. Mader R. Diffuse idiopathic skeletal hyperostosis: time for a change. J Rheumatol 2008; 35: 377-9.

2. Cammisa M, De Serio A, Guglielmi G. Diffuse idiopathic skeletal hyperostosis. Eur J Radiol 1998; 27 (Suppl 1): 711.

3. Mata S, Fortin PR, Fitzcharles MA, et al. A controlled study of diffuse idiopathic skeletal hyperostosis. Clinical features and functional status. Medicine (Baltimore) 1997; 76: 104-17.

4. Forestier J, Rotes-Querol J. Senile ankylosing hyperostosis of the spine. Ann Rheum Dis 1950; 9: 32130.
5. Caron T, Bransford R, Nguyen Q, Agel J, Chapman J, Bellabarba $C$. Spine fractures in patients with ankylosing spinal disorders. Spine (Phila Pa 1976) 2010; 35: E458464.

6. Mader R, Novofastovski I, lervolino $S$, et al. Ultrasonography of peripheral entheses in the diagnosis and understanding of diffuse idiopathic skeletal hyperostosis (DISH). Rheumatol Int 2015; 35: 493-7.

7. Westerveld LA, Verlaan JJ, Oner FC. Spinal fractures in patients with ankylosing spinal disorders: a systematic review of the literature on treatment, neurological status and complications. Eur Spine J 2009; 18: 145-56.

8. Akhtar S, O'Flynn PE, Kelly A, Valentine PM. The management of dysphasia in skeletal hyperostosis. J Laryngol Otol 2000; 114: 154-7.

9. Mader R, Sarzi-Puttini P, Atzeni F, et al. Extraspinal manifestations of diffuse idiopathic skeletal hyperostosis. Rheumatology (Oxford) 2009; 48: 1478-81.

10. Sarzi-Puttini P, Atzeni F. New developments in our understanding of DISH (diffuse idiopathic skeletal hyperostosis). Curr Opin Rheumatol 2004; 16: 287-92.

11. Mazières B. Diffuse idiopathic skeletal hyperostosis (Forestier-Rotes-Querol disease): what's new? Joint Bone Spine 2013; 80: 466-70.

12. Resnick D, Niwayama G. Radiographic and pathologic features of spinal involvement in diffuse idiopathic skeletal hyperostosis (DISH). Radiology 1976; 119: 55968.

13. Whang PG, Goldberg G, Lawrence JP, et al. The management of spinal injuries in patients with ankylosing spondylitis or diffuse idiopathic skeletal hyperostosis: a comparison of treatment methods and clinical outcomes. J Spinal Disord Tech 2009; 22: 77-85.

14. Yunoki M, Suzuki K, Uneda A, Okubo S, Hirashita K, Yoshino K. The Importance of Recognizing Diffuse Idiopathic Skeletal Hyperostosis for Neurosurgeons: A Review. Neurol Med Chir (Tokyo) 2016; 56: 510-5.

15. Utsinger PD, Resnick D, Shapiro R. Diffuse skeletal abnormalities in Forestier disease. Arch Intern Med 1976; 136: 763-8. 